\begin{tabular}{lc|c|c|c|c}
\hline \hline \multicolumn{2}{l|}{ II Social Structure } & $=$ very weak & weak & strong & very Strong \\
\hline 周 & 邊 & $58.5-70.5$ & $49.8-55.4$ & $\ldots \ldots$ & $\ldots \ldots$ \\
\hline 中 & 間 & $\ldots \ldots$ & $45.4-56.8$ & $28.3-41.7$ & $\ldots \ldots$ \\
\hline 都 & 心 & $\ldots \ldots$ & 48.4 & $28.3-37.2$ & 13.0
\end{tabular}

經濟構造 此の目的の営に職業別人口の圶有業人口に對寺る百分率を用ふ。商業は 商業中心である City に多く，殊に Prague I 双びV 區は夫々 39.6，47.9\%に達し， 其他の內市でる 30-34\% である。之に反し中間帶，內市の一部は 19.8-25.9\%，周 邊は多くて 16.3-18.0，少い、所は 11.9-14.7\%に過ぎ奴業は socially weakの 周邊部に 50\% 上上, 都心で 24.2-45.1\%で，V1tava 河左岸の低地は特に高率である。 公務自由業は行政中心地の Castle (Prague IV 區)の33.2\%を中心とし，他の 3 區 25.5-27.8\%に多い。次には商業中心地の Prague II, $\mathrm{V}$ 等に之と關係密接な公 務自由業が 18.8--22.3\% を占める。此等を綜合すると商業帶（之に有業人口の $30 \%$ が從事), 丕務自由業帶 (之に $18.9 \%$ 以上從事)，工業帶 (之に $50 \%$ 以上從事) が區別 される。佾所屬不明の 7 區が殘るが其の發達は將來注昌さるべきものであらう。

以上に於て，都市發展の項目內で地理的證明が餘り蘚明でない樣に思はれる。併し 本論文の主題は夫れ以下にあるのであるし，之等は又都市の構造乃至地域を念頭に於 て人口の解析を行つた點で興味深い。特に子供の率や都心部が overaged（老年者過 多)である事實と說明は地理學的にも社會學的にも面白い取披ひであらう。 木两信 藏

\title{
北東サガレンの氮候 〔D. N. Tregubov]
}

1935 年 4 月北樺太オ八市に於て出版されたディー，エヌ，トレグーボフ (D. N. Tregubov）著「北東サガレン氣候の特質」中より主雾氣象統計資料を抄錄した。本 著は大部分オ八を中心として記載されてあるが，大體北樺太北部の氣候の大要を推知 せしめるに足ると思ふ。

全要觀測地はオ八，モスカリオ，ウェレシチャギノ，ラングル島で概略位置は附圖 に示して置いた。觀測地の經，緯度は次の通である。以上の外に北㩰太石油會社では 1928 年 6 月以來氯象觀測を續けてるる。次に氣溫，風向，氣簒，雨量等を逐示表示 


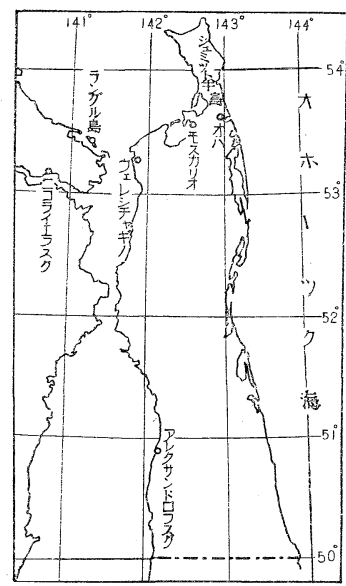

北㮖太氧象觀测地略圖

少る。

オハに於ける氟溫の最高は 8 月，最低は 1 月に賞り， 夏期の氣候は海洋的で冬期には大陸的々なる。その原因 は主に風向の變化にある。下に風向の頻度を示す。(第3 表 I）若し北東，事，南真及南風を第 1 類とし你を第 2 類とせば之は更に第 3 表II の如く要約せられる。

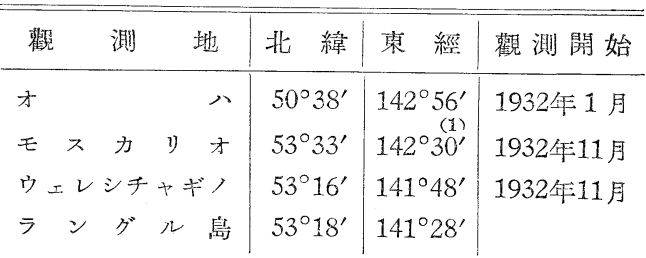

証(1)原蕃には $142^{\circ} 06^{\prime}$ とあるが $142^{\circ} 30^{\prime}$ (根測) の誤と考へる

第1表平均氣泪（攝氏度）

\begin{tabular}{|c|c|c|c|c|c|c|c|c|c|c|c|c|c|c|}
\hline 地 & $T$ T奴 & 1 月 & & & & 5 月 & 6月 & 7月 & 8月 & s & & & & \\
\hline 浩 & 3. & & & & & & & & & & 4 & & & \\
\hline & 70 & & & 7 & & & 1 & & & & 1.9 & 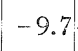 & & -2 \\
\hline 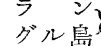 & 10 & & & & & & & & & & 2.6 & -7.7 & 0 & -2 \\
\hline 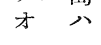 & & & & & & 6 & & & & & .2 & -6.3 & -14.9 & 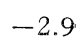 \\
\hline
\end{tabular}

(備考 オ八の氣溫は日本側觀測に據る)

第 2 表 ソヴェート側オ八觀測所の本均氣溫及氣溫極數（攝氏度）

\begin{tabular}{|c|c|c|c|c|c|c|c|c|c|c|c|c|c|c|}
\hline & 次 & 1 月 & 2 月 & 3 月 & 4 月 & 5 月 & 6 月 & 7 月 & 8 月 & 9 月 & 10 月 & 11月 & 12 月 & 全年 \\
\hline 夾 & 32 & $x_{1}$ & 7.8 & 0 & 5.4 & 0.3 & 6.1 & 11.8 & 12.5 & 10.5 & 2.7 & 1 & 4.0 & -2 \\
\hline & 3 & 3 & 9.1 & -15.2 & -4.3 & 2.3 & 4 & 12 & 15.4 & 10.8 & 4.1 & 4.5 & 9.5 & -1 \\
\hline 篮 & 34 & -11.2 & -13.1 & -10.1 & -4.0 & 2.2 & 10.9 & .1 & 14.0 & 10.4 & 1.7 & & 12.6 & -0 \\
\hline & & & & & 7.5 & 23.5 & & & & 25.0 & 1 & & 0. & \\
\hline & 低 & & & & & 30 & -5.0 & 0.5 & 0 & 1. & 8.7 & & -32.5 & \\
\hline
\end{tabular}


笨 3 表 風向 頻 度 \% オ八

\begin{tabular}{|c|c|c|c|c|c|c|c|c|c|c|c|c|c|c|c|c|}
\hline & 風 & 向 & & 1 月 & 2 月 & 3 月 & 4 月 & 5 月 & 6 月 & 7 月 & 8 月 & 9 月 & 10 月 & 11月 & 12月 & 全年 \\
\hline \multirow{8}{*}{ (I) } & \multicolumn{3}{|c|}{ 北 } & 5 & 10 & 8 & 10 & 8 & 5 & 7 & 7 & 7 & 8 & 6 & 7 & 8 \\
\hline & 北 & 柬 & & 5 & 6 & 9 & 11 & 13 & 15 & 15 & 13 & 14 & 10 & 6 & 5 & 10 \\
\hline & & - & 3 & 7 & 10 & 16 & 14 & 18 & 14 & 11 & 9 & 4 & 1 & 9 \\
\hline & 南 & 牙 & & 1 & 1 & 6 & 16 & 25 & 35 & 28 & 23 & 22 &  & 5 & - & 14 \\
\hline & \multicolumn{3}{|c|}{ 南 } & 1 & 4 & 3 & 7 & 9 & 11 & 13 & 9 & 11 & 6 & 4 & 1 & 7 \\
\hline & 南 & 元 & & 3 & 3 & 1 & 7 & 5 & 10 & 7 & 10 & 6 & 12 & 13 & 6 & 7 \\
\hline & \multicolumn{3}{|c|}{ 西 } & 39 & 25 & 17 & 15 & 6 & 5 & 6 & 10 & 12 & 20 & 32 & 43 & 19 \\
\hline & 北 & 西 & & 46 & 48 & 49 & 24 & 18 & 5 & 6 & 14 & 17 & 29 & 30 & 37 & 26 \\
\hline \multirow{2}{*}{ (II) } & 東 & & & 7 & 1 & 25 & 44 & 63 & 75 & 74 & 59 & 58 & 11 & 19 & 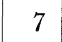 & 40 \\
\hline & 西 & 㜍 & & 93 & 86 & 75 & 56 & 37 & 25 & 26 & 41 & 42 & 69 & 81 & 93 & 60 \\
\hline
\end{tabular}

（備考 1928 年より 1934 年迄の本均）

郎ら大陸風の活動は 5 月より 9 月迄の間其の勢を垁ひ，海上氣流の影響が著しく， 夏期の前牛に於ては比較的低溫なる以外，オホーック海の濃霧を窟らし，夏期の後牛 には島の該部分を著しく冷却せしめる。之に反し冬期には大陸風の影響で著しく寒氣 を增す。更にオ八に於ける 1 ケ年の舞溫變化に於て冬期より夏期への轉換は極めて徐 徐に行はれるに反し，冬期の再歸は急に行はれる。之は大陸的季節風が海洋的季節風 に此して遥かに有力なるを物語る。

大陸的風の全年頻度 60\%であり，風速も遥かに大であることもこの事實を說明する ものである。各月の平均風速は下の如くである。(每少米)

1 月 $6.2 ， 2$ 月 $5.5 ， 3$ 月 $5.7 ４$ 月 $5.4 ， 5$ 月 $5.2 ， 6$ 月 $5.0 ， 7$ 月 $4.9 ， 8$ 月 $4.7 ， 9$ 月 5.9，10月 7.3，11月 5.7，12 月 6.5, 全年 5.7 となる。更に此等の平均風速を風向別 に示すと, 北風 6.1 , 北東風 5.3 , 東風 5.4 , 南東風 5.6, 南風 5.6 , 南西風 5.5 , 西風 5.4, 北西風 5.9 となる。厼オ八に於て雚測された最大風速は北西風每秒 28 米のもので あつた。

次は旋風の活動並に氣烈の變化である。サガレン島を通過する旋風の中心は主とし てオハの南方へ進み, 從つて島の北東部は此等大氣活動の背部若くは北部の寒冬な領 域に置かれる。更に冬期旋風の大部分はアジア大陸よりオホーツク海に移動する際に， 荄海の奧に進むに從つて勢力を增大する。之に對し6月より9月末にかけて發澾する 赫風はオホーツク海に近づくや勢力を失ふことが㞗 るである。 
佮注意すべきは夏より秋にかけて起るサガレン灣の北西暴風であつて，海上交通上 最も有害なものである。殊に秋期には長時間に互つて暴風を遈うし，アムール河口に 於ては强風を見る事殆ど通例でるる。特に每年11月及12月に於ける北よりの暴風は 猛威を極め, ラングル島，モスカリオ，ヴェレシチャギノに於ては满潮時に際し海水 の大上昇を來すことがある。

旋風を發生地別に百分比に分つてみると䔪洲旋風 $40 \%$ ，支那旋風 $25 \%$ ，ザバイカル 旋風 $22 \%$, 南支那旋風 $10 \%$, ヤクーック旋風 $3 \%$ となる。而して旋風の進行速度は 12 月に於て平均 51 料 (最大), 8 月に於て本均 32 籸 (最小) を示してるる。

オ八に於ける 1 ケ年の月別氣壓を㸴究した所，特定の長期變化は發見するに至らず， 氣遮の幾分高い月として 2 月，9 月支 10 月を擧げ得るのみである。文每日の變化を調 查するに低氣壓と高氣懨との艾替は每月頗る頻繁であることを示し，サガレン北東部 にては全年に互つて旋風の活動が休止しないことを證する。才八に於て觀測された最

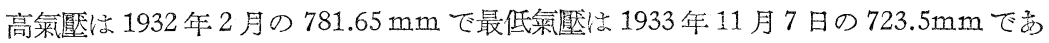
つた。サガレン附近の平均氣遮は次の如くである。

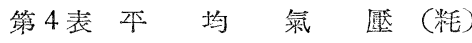

\begin{tabular}{l|r|r|r|r|r|r|r|r|r|r|r|r|r|r}
\hline \hline 觀測地 & 1 月 & 2 月 & 3 月 & 4 月 & 5 月 & 6 月 & 7 月 & 8 月 & 9 & 月 & 10 月 & 11 月 & 12月 & 全年 \\
\hline オ & 八 & 759.2 & 760.8 & 758.3 & 756.1 & 758.5 & 758.2 & 757.7 & 758.2 & 760.3 & 760.3 & 757.8 & 758.0 & 758.6 \\
尼 & 港 & 61.2 & 61.5 & 59.2 & 56.9 & 57.0 & 54.7 & 54.8 & 55.4 & 57.2 & 57.7 & 58.8 & 59.0 & 57.8 \\
亞 & 港 & 61.6 & 62.1 & 60.4 & 57.9 & 54.0 & 56.5 & 55.8 & 56.5 & 58.9 & 59.2 & 59.7 & 59.4 & 58.5
\end{tabular}

次に降永量に就いて述べる。 5 月より 8 月末に至る期間に於て最大降永量を示して るるが，全年降水量は堵しく少量で 300 楀內外であつて，サガレン島最北部が牛乾燥 地帶に屬することを知る。第 5 表Iにオ八に於ける各年の降水量を示す。此の外ヴェ レシチャクギノにては 1933 年に 319.3 粍, 1934 年に 251.9 秏を示した。

次にはオ八に於る積雪量を示す。1932 年より 1935 年末に至る期間 (第 5 表 II) オ八に於ける全年本均濕度は，1932 年 $86 \% ， 1933$ 年 $82 \% ， 1934$ 年 84\%であ る。各年に於ける變化を見るに大體 2 個宛の最大並びに最小の㬎度を示す月がある。 最大を示孛のは第 1 は 2 月又は 3 月，第 2 は 7 月又は 8 月であり，最小を示すのは， 第1は4月，6月の間，第 2 は11月にある。之郎ら寒期に於ける濕度變化は正常であ つて，䈦期に大つてより季節風の特徵を示吉證左と見られる。1 ケ月の最大平均濕度 
第 5 表 オ八に於ける降水量, 積雪量, 雲量, 降水日數

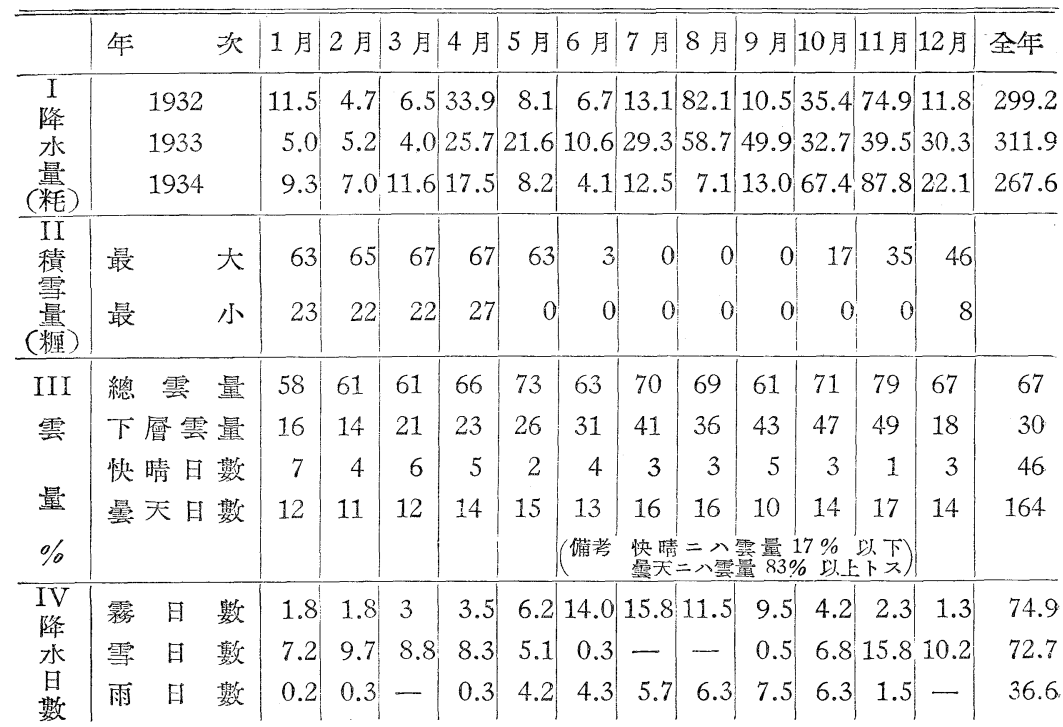

第 6 表 無融雪及無巌寒期間（於オ八）

\begin{tabular}{|c|c|c|c|c|c|}
\hline 雪 解 & ナキ 期 & & 览 寒 & ナ キ 期 & \\
\hline 始 & 終 & 日 數 & 始 & 終 & 日 數 \\
\hline 1928-10-31 & $1929-4-25$ & $177^{\text {日 }}$ & $1929^{\text {年 }}$ 月-12 & $1929-10-17^{\text {年 }}$ & $\begin{array}{r}\text { 日 } \\
128\end{array}$ \\
\hline $1929-10-27$ & $1930-4-14$ & 170 & $1930-6-13$ & $1930-10-12$ & 122 \\
\hline $1930-10-28$ & $1931-3 \cdot 20$ & 145 & $1931-6-20$ & $1931-10-3$ & 106 \\
\hline $1931-11-18$ & $1932-4-18$ & 153 & $1932-6-5$ & $1932-9-28$ & 116 \\
\hline $1932-11-26$ & $1933-4-3$ & 129 & $1933-6-15$ & $1933-9-24$ & 102 \\
\hline $1933-12-22$ & $1934-3-18$ & 87 & $1934-5-31$ & 1934- 9-30 & 123 \\
\hline $1934-11-20$ & $1935-4-13$ & 145 & & & \\
\hline
\end{tabular}

は 1932 年 3 月の $91 \%$ であり，最小なるは1933 年 6 月の $75 \%$ である。

オ八に於ける雲量に就いては第 5 表 III を揭げる。(1932 年より1934 年迄の3 万年 の本均)

各年に於ける平均全年雲量は $67 \%$ に近い。快晴日數の最大なるは 1 月より 3 月に至 る期間及び 9 月であつて，曇天日數の最大なるは 5 月及 11 月である。 5 月の尝天なの 
は春期の到來の遲々たる原因となる。

7 ケ年に酉る霧，雪及び雨の日數は第 5 表 IVに示す通りである。 最後にオ八に於る雪解無き期間文び嚴寒なき期間を表示して置く（第6 表)。

牛島信 戔 